\title{
A tragédia que a Copa legou ao Brasil - as Jornadas de Junho e a efervescente anticorrupção ${ }^{1}$
}

Arlei Sander Damo

\section{Resumo}

Este texto explora as conexões entre os megaeventos esportivos realizados no Brasil em 2014 e 2016, em particular a Copa das Confederações, de 2013, e os megaprotestos que ficaram conhecidos como Jornadas de Junho. As publicações produzidas logo após essas manifestações enfatizaram a participação de coletivos de esquerda, aqui tratados como insurgentes, e a multiplicidade de pautas. Investigações a posteriori, com as quais procuro dialogar, tendem a enfatizar a emergência de pautas conservadoras e antidemocráticas, aqui tratadas como intransigentes. Acompanho aqueles textos que enfatizam o discurso anticorrupção como o principal destaque das Jornadas de Junho, em torno do qual se produziu uma espécie de consenso improvável, porque aproximou e confundiu insurgentes e intransigentes. 0 objetivo principal é mostrar como a preparação para os megaeventos e, particularmente, as alianças entre dirigentes esportivos, grandes empreiteiras e políticos de diferentes matizes, incluindo-se Lula e Dilma, mobilizaram críticas generalizadas em relação à gestão do Estado. Uso o conceito de escala para mostrar como principiaram as manifestações de 2013, antes das Jornadas de Junho, e de como elas adquiriram e perderam tração. Um dos eventos centrais nesse processo, tanto de mudança de escala como de torção ideológica, foi a aparição acompanhada de vaias à presidente Dilma ao lado do então presidente da FIFA, Joseph Blatter, quando da abertura da Copa das Confederações.

\section{Palavras-chave}

Jornadas de Junho. Megaeventos no Brasil. Corrupção.

\section{Abstract}

This text explores the connections between the sporting mega events held in Brazil, in particular the Confederations Cup (2013), and the mega-protests known as Jornadas de Junho (loosely translated as June Journeys). Publications immediately following such protests emphasized the participation of left-wing collectives, referred here as insurgents, and the multiplicity of agendas. Later investigations, with which I seek to dialogue, tend to emphasize the emergence of conservative and

\footnotetext{
${ }^{1}$ Este texto é uma versão modificada de palestra realizada no encerramento do Seminário CIDADES, nas dependências da UERJ, em 4 de julho de 2018. Sou especialmente grato a Lia de Mattos Rocha e Frank Davies pelo convite.

2 Professor do Programa de Pós-Graduação em Antropologia Social/UFRGS. E-mail: arleidamo@gmail.com.
} 
undemocratic guidelines, referred here as intransigent. I follow those texts that emphasize the anticorruption discourse as the main highlight of the June Journeys because it brought together and mixed up insurgents and intransigents. The main objective is to show how the preparation for the 2014 World Cup - in particular the alliances between sports leaders, construction developers and politicians of different backgrounds, including Lula and Dilma - has mobilized widespread criticism regarding state management. I use the concept of scale to show how the 2013 protests, before the June Journeys, and how they gained and lost traction. One of the central events in this process, both of scale and ideological twists, was when President Dilma was booed while standing next Joseph Blatter, the FIFA President at the time, at the opening of the Confederations Cup.

\section{Keywords}

Journeys. Mega-Events in Brazil. Corruption.

Em sociedades democráticas, protestos no entorno da Copa ou dos Jogos Olímpicos ${ }^{3}$ são esperados, razão pela qual o projeto “Megaeventos esportivos no Brasil - uma perspectiva etnográfica", desenvolvido a partir de 2010 - possuía um eixo voltado à temática das mobilizações políticas. ${ }^{4}$ Até 2013 nossa atenção esteve focada nas ações dos Comitês Populares da Copa, organizados para dar suporte às comunidades ameaçadas por remoções forçadas e na mobilização dos povos indígenas, mas sem descartar a possibilidade da entrada em cena de outros coletivos. ${ }^{5}$ A investigação não previa, obviamente, a escala das manifestações ocorridas ao longo de 2013, em particular aquelas que ficariam conhecidas como

\footnotetext{
3 Por economia de linguagem, "Copa" refere-se à "Copa do Mundo de Futebol Masculino", competição organizada a cada 4 anos pela Federação Internacional de Futebol Association (FIFA); quando estiver me referindo à "Copa das Confederações", organizada pela mesma entidade, farei por extenso. Se estiver me referindo a uma edição em particular desses eventos, declinarei o ano, a menos que isto esteja subentendido. Vale a mesma orientação para os "Jogos Olímpicos", que se referem aos "Jogos Olímpicos de Verão", evento organizado pelo Comitê Olímpico Internacional (COI).

${ }^{4}$ O projeto constava, pois, de quatro módulos principais, a saber: reforma e construção dos estádios; eventos satélites; construções narrativas; protestos e manifestações. O projeto contou com o financiamento do CNPq, entre 2012 e 2014, e com o suporte da UFRGS/CNPQ, entre 2012 e 2016, através da concessão de bolsas de Iniciação Científica. Participaram do projeto estudantes de diferentes níveis, da graduação ao doutorado. Farei referência a eles quando conveniente ao longo do texto, exceto nos casos de Moisés Kopper e Julia Cardoni, cuja participação não resultou em publicações.

${ }^{5}$ Sobre a mobilização de resistência às desocupações, tendo como ponto de partida o Comitê Popular da Copa de Porto Alegre, conferir Araújo (2014), Mesomo (2015) e Mesomo e Damo (2016). Para o caso da mobilização indígena, ver Hermann e Damo (2014). Outras publicações derivadas do projeto "Megaeventos Esportivos..." a este respeito serão referidas no momento oportuno no decorrer do texto.
} 
Jornadas de Junho (JsJ), emaranhadas à Copa das Confederações, evento preparatório à Copa 2014.

O caráter multifacetado das reivindicações que ganharam as ruas e a diversidade das pessoas e grupos tornaram as JsJ um desafio à síntese. Mais que isso, ensejaram uma disputa pelo sentido dos protestos, o que na maioria das vezes acabou por reduzi-los em termos de complexidade. Alguns intérpretes sugeriram tratar-se de uma crise de representação da democracia liberal, haja vista a tendência de rejeição às intermediações institucionais - partidos políticos, sindicatos, entidades de classe ou equivalentes. Outros preferiram destacar o foco voltado para a crítica à qualidade dos serviços públicos, especialmente os de saúde e educação, cujas menções foram frequentes em cartazes portados individualmente nas ruas ou nas hashtags mais curtidas e retuitadas. Diz-se que tudo principiou com a mobilização contra o aumento das passagens urbanas, até se propagar a ideia de que a revolta "não era apenas pelos 20 centavos". Desse jargão tantas vezes repetido, poder-se-ia deduzir que os protestos foram contra o establishment, e a queda vertiginosa dos índices de aprovação dos políticos de todos os matizes ideológicos corrobora a suspeita. Ampliando-se a escala temporal dos eventos - antes e depois da JsJ -, é possível vislumbrar o recrudescimento e a perda de suporte dos grupos, aqui nomeados insurgentes, responsáveis por lançar as manifestações ainda nos primeiros meses de 2013. Posteriormente às JsJ nota-se a articulação e o protagonismo de outros grupos, de matiz contrária, aqui denominados intransigentes. ${ }^{6}$

O objetivo deste texto é apresentar algumas hipóteses sobre como teria ocorrido a torção das pautas no contexto mesmo em que se produziram as JsJ. A bibliografia em Ciências Sociais vinda à tona na esteira dos fatos tendeu a enfatizar o ponto de vista dos insurgentes, ao passo que em publicações mais recentes enfatiza-se a emergência do que seriam os intransigentes. Passados pelo menos um ciclo de Copa - em breve um ciclo Olímpico - e, sobretudo, duas

\footnotetext{
${ }^{6}$ A categoria insurgente vem sendo usada pela bibliografia e carece de maiores justificações, uma vez que os próprios movimentos se reconhecem nela (BENTES, 2014). Quanto à categoria intransigentes, trata-se de uma escolha ad hoc, uma espécie de guarda-chuva para agrupar pessoas e grupos que se definem por posições "à direita" do espectro político, em que pese muitas tenham se manifestado contra a política e reivindicado pautas antidemocráticas e de ultradireita, lembrando, em muitos aspectos, o fascismo e o integralismo. Todavia, alguns desses movimentos orbitam num espectro mais liberal, com pautas de ocasião, caracterizando-se como "antipetistas", "moristas" (em referência ao juiz de primeira instância responsável pela condenação do ex-presidente Lula em 2018) e "lavajatistas" (em alusão à controversa operação do Ministério Público que culminou com a condenação de Lula e outros políticos e empresários destacados). Intransigentes me parece um termo mais englobante do que reacionários e evita que suas pautas sejam ridicularizadas, simplesmente, como frequentemente ocorre com as Ciências Sociais quando se voltam para públicos com os quais não têm simpatia.
} 
eleições presidenciais, um impeachment e outros eventos de porte - inclusive na esfera política internacional - é possível inserir na narrativa sobre as JsJ um antes e um depois. Isto é essencial para se perceber a "torção ideológica" - alguns autores falam em virada - que contribuiu para promover uma assertiva com a qual está de acordo boa parte das investigações mais recentes: como foi possível essa torção e, fundamentalmente, em que medida os megaeventos esportivos teriam contribuído para tal?

Pretendo, pois, discutir algumas hipóteses acerca das conexões entre as JsJ e a Copa da Confederações. Se observada a cronologia, apenas, a conexão é óbvia, tanto que todos os textos sobre as JsJ se referem à simultaneidade dos eventos, mas, salvo exceções, poucos avançam em relação à qualidade dessa conexão. $\mathrm{O}$ argumento aqui desenvolvido é de que os megaeventos esportivos impactaram as JsJ de modo mais intenso do que a bibliografia supõe. Em que pese a multiplicidade de pautas levadas às ruas pelos insurgentes, poucas prosperaram. A contestação à qualidade do transporte público - incluindo-se o preço, que foi um disparador - produziu resultados pífios. Esta pauta, inclusive, tinha escassa relação com os megaeventos esportivos, à exceção de algumas cidades, como o Rio de Janeiro ${ }^{7}$. Já as críticas generalizadas aos serviços públicos, que acabariam minando a popularidade de quase todos os políticos que ocupavam cargos eletivos à época, em particular a da presidente Dilma Rousseff, possuem uma relação mais estreita com os megaeventos, em particular com as narrativas construídas sobre os aportes públicos visando às reformas e/ou construções dos estádios que sediariam a Copa.

A confrontação entre a exuberância das novas arenas e a precariedade de hospitais e escolas públicas era de fácil assimilação. Ainda que os investimentos nas áreas de saúde e de educação estivessem em alta ou que o total de recursos empenhados nos estádios, via financiamento, fosse menos de $5 \%$ da soma do orçamento anual dos ministérios da Saúde e da Educação, a narrativa contrastante tornou-se verossímil. Os insurgentes, em sua maioria, eram usuários efetivos dos serviços públicos e, portanto, poderiam reivindicar a legitimidade para contestar as novas arenas - "Da Copa eu abro mão, mais saúde e educação". Além de suntuosas, elas estavam destinadas ao passatempo das elites, contrariamente aos velhos estádios, mais generosos com as classes populares. Os

\footnotetext{
7 Pelo fato de sediar jogos da Copa, incluindo-se a final, e os Jogos Olímpicos, a cidade do Rio de Janeiro certamente foi a mais impactada com a realização dos megaeventos no Brasil. Em termos de mobilidade urbana e remoções forçadas, foi a cidade que mais teve intervenções e as mais portentosas (GUTTERRES, 2014), em termos econômicos e estéticos, razão pela qual o Rio de Janeiro constitui, em boa medida, um caso à parte.
} 
intransigentes não eram usuários de serviços públicos básicos, como saúde e educação, e seriam beneficiados com as novas arenas, mas as escrachavam sob o argumento de que seus impostos estavam sendo mal geridos, pois alguns estádios estavam condenados à obsolescência e outros eram suspeitos de superfaturamento. Ainda que por razões distintas, todos se voltaram contra as arenas, a Copa, os megaeventos e os seus promotores - a FIFA e o Governo Federal, sobretudo. Todos contra o Estado; eis uma das sínteses possível das JsJ.

Para identificar o ponto de torção ideológica, em que os discursos de uns e outros aparecem emaranhados, é importante observar as pautas que sobressaíram após as JsJ. Pelo que a bibliografia mais recente indica, foi o discurso anticorrupção (MELO; VAZ, 2018; MENDONÇA, 2018)8 , que emergiu soberano das JsJ. Articulado pela grande mídia (OLIVEIRA, 2018), retornou às ruas intermediado por grupos tais como o Movimento Brasil Livre (MBL), o Vem Pra Rua e o Revoltados on Line, "filhos diletos" das JsJ. ${ }^{9}$ Pretendo, em diálogo com os textos que vão nessa direção, apresentar argumentos pontuais que ajudem a entender como a corrupção se sobressaiu em relação a outras pautas, suscitando, inclusive, a criação de movimentos que até então não existiam e dando respaldo popular à megaoperação Java-Jato, desencadeada no início de 2014 e responsável indireta pelo impeachment da Presidente Dilma, em 2016, pelo encarceramento do ex-presidente Lula - o principal avalista dos megaeventos esportivos - e decisiva nas eleições de 2018. Em uma enquete realizada em 2012, $70 \%$ dos entrevistados se declaravam favoráveis à realização da Copa no Brasil eram $79 \%$ em 2008, quando as obras sequer haviam sido iniciadas -, 76\% acreditavam haver corrupção (DAMO; OLIVEN, 2014, p. 155-6). Independentemente de haver corrupção efetiva, havia a crença na sua existência, e isso é preciso ser levado em conta quando se analisa a torção no sentido dos protestos no decurso das JsJ.

O texto está subdividido em três partes. Na primeira, recupero alguns argumentos trabalhados com mais profundidade em textos anteriores, destacando, basicamente, o fato de que o prefixo mega acoplado a eventos como

\footnotetext{
8 "[D]iferentemente da tese de que a ampliação do movimento propiciou a abertura irrestrita da pauta, sustentamos um outro posicionamento: a entrada do tema específico 'combate à corrupção' foi que permitiu a massificação das manifestações. $O$ fato de a corrupção ter sido o único tópico de reivindicação que permaneceu como bandeira de luta nas manifestações de 2015 e 2016 endossa essa linha de argumentação." (MELO; VAZ, 2018, p. 31)

${ }_{9}$ Para um apanhado dos movimentos ditos intransigentes que emergiram ou se consolidaram com as JsJ consultar Gohn (2017). Para uma discussão sobre novos movimentos liberais que atuam no formato de think tanks, sugiro os trabalhos de Rocha (2015) e de Barbieri (2018), este último em perspectiva etnográfica.
} 
as copas e os jogos olímpicos demanda uma produção discursiva a cargo do marketing que serve às agências esportivas. Também destaco o conceito de escala, essencial tanto para a compreensão desta produção quanto para o entendimento da arquitetura dos eventos esportivos e seus nexos com outros eventos. Na segunda parte, realizo uma síntese dos arranjos institucionais agências esportivas, grandes empreiteiras e Governo Federal - e de certas decisões concernentes à reforma e construção de arenas para a Copa 2014, processo no decurso do qual sobressaíram críticas de diferentes matizes políticas relativas à gestão de recursos públicos. A reforma e a construção das novas arenas produziram um discurso eloquente, verossímil e facilmente assimilável, de que tais empreendimentos eram moralmente injustificáveis. Na terceira parte procuro mostrar como essa narrativa contra o Estado, em sentido lato, seria uma espécie de decantação de tudo o que se dizia contra a Copa. Diálogo com parte da bibliografia sobre as JsJ, especialmente aquela que enfatiza o discurso anticorrupção como o grande destaque. Ao longo do texto alterno referências bibliográficas sobre as JsJ com informações etnográficas colhidas ao longo do projeto "Megaeventos Esportivos...". No que concerne às manifestações que precederam e sucederam às JsJ - cuja escala foi nacional - me reportarei com frequência a Porto Alegre, em parte por razões etnográficas, de outra pela importância que tiveram as mobilizações nessa cidade antes que elas adquirissem escala nacional e se convertessem nas JsJ.

\section{Metanarrativas para (mega)eventos}

Eventos, como diria Sahlins (1990), são os acontecimentos e suas significações. Eu acrescentaria, para o caso dos eventos esportivos, a imaginação, pois parte expressiva das significações não apenas precedem senão que modulam os acontecimentos em si. Para dar uma ideia da força dessas narrativas que se antecipam aos fatos, criando sentidos, expectativas e justificativas, retomarei o relato sucinto de uma "descoberta" realizada em janeiro de 2014, ocasião em que preparava uma publicação (DAMO; OLIVEN, 2014). Em certa circunstância, julguei pertinente emoldurar com cifras o argumento sobre o impacto da Copa do Mundo; um número relacionado à audiência, como é usual em toda a sorte de publicações do gênero. Não lembro com precisão quais os termos utilizados na busca realizada no Google, mas entre os primeiros resultados dela constava uma matéria cujo título dizia: “Copa de 2014 deve injetar R\$ 142 bilhões na economia 
brasileira". ${ }^{10}$

Só poderia ser mais um desses prognósticos que a imprensa esportiva notícia como sendo de uma "consultoria internacional", sem sequer informar a fonte. Havia realizado uma revisão bibliográfica a respeito da construção dessas estimativas, sendo convencido de que careciam de fundamento metodológico e, na maior parte das vezes, eram produzidas por encomenda (ANDREFF, 2010). O interesse, portanto, não deveria centrar-se na matéria, mas na fonte por ele indicada: um dossiê produzido pela agência de consultora Ernest \& Yong (atualmente E\&Y) em parceria com a Fundação Getulio Vargas (E\&Y/FGV, daqui por diante).

Confrontando-se as predições sobre geração de empregos do dossiê "Brasil sustentável: impactos econômicos da Copa do Mundo 2014" com os dados do CAGED, a discrepância mostrou-se espetacular (DAMO, 2016, p. 29-30). Andreff estava coberto de razão, mas talvez eu não devesse ter ignorado outra faceta dos relatórios desse tipo - dispositivos sociotécnicos, em termos de Callon (2013, p. 368 ) - dado que eles poderiam ser convincentes mesmo quando equivocados. Em razão das lacunas metodológicas, as opiniões mais recomendáveis não recomendariam relatórios tais como o "Brasil Sustentável", e submetido à prova ele não resistiu. Em que pese se defina como um dispositivo "técnico", sua narrativa flerta com a ficção ao apresentar números que, dispostos em tabelas e gráficos, sugerem uma fábula de natureza performativa. Aquilo que é apresentado como projeção não passa de um cenário imaginativo, uma narrativa ilusória - em sentido empregado por Bourdieu (1995) à noção de illusio, equivale a interesse ou libido. Realizando uma pesquisa mais detalhada a respeito da trajetória do relatório da E\&Y/FGV, foi possível identificar uma lista extensa de discursos políticos e de eventos nos quais a peça figurou como argumento - tipo lacração - para justificar os investimentos públicos demandados pelos megaeventos.

Outra finalidade de relatórios sociotécnicos, tais como o da E\&Y/FGV, é a própria construção da ideia de megaevento. Dizendo de maneira direta, as agências promotoras necessitam acoplar o prefixo mega ao de evento, podendo isso ser realizado de múltiplas formas. Uma delas é a veiculação deliberada de estimativas alvissareiras, ainda que precariamente fundamentadas. Outra, igualmente recorrente, é conectar as performances esportivas com eventos de naturezas distintas - o turismo, a empregabilidade, as construções ecológicas, as obras de mobilidade urbana, e assim por diante - sendo tais conexões pensadas

${ }^{10}$ Disponível em: http://g1.globo.com/economia-e-negocios/noticia/2010/06/copa-deve-injetar-r142-bilhoes-na-economia-brasileira.html. Acesso em: 15 nov. 2019. 
por agências de marketing que assessoram a FIFA e o COI, como de resto é usual no mundo corporativo.

Pode-se definir um megaevento, em termos genéricos, como um conjunto de eventos conectados, uma modalidade de assemblage (ONG; COLLIER, 2005). Mega não é um prefixo apenas; é uma questão de escala, a ser construída concreta e imaginariamente. A questão da escala é, por assim dizer, um problema clássico da antropologia, tanto no que se refere à própria produção do conhecimento - de como se passa do particular ao geral, do individual ao coletivo, e assim por diante - quanto das questões com as quais ela lida - o local e o global, por exemplo. No que concerne à produção contemporânea que aborda essa questão, gostaria de destacar ao menos três qualidades atinentes à noção de escala. ${ }^{11}$

Primeiro, a ideia de que a escala é uma construção discursiva - o local e o global não existem como entidades per si, assim como não existe, necessariamente, oposição entre elas. A discussão adquiriu projeção - ou escala, com o perdão da redundância - com o debate sobre a globalização e os projetos de cooperação transnacional, encaixando-se perfeitamente aos megaeventos esportivos. A segunda questão tem a ver com o fato de que escala não implica somente uma noção de grandeza, antes de arranjos - conexões, articulações, enquadramentos, etc. Em muitos casos - ou na maioria deles - as coisas que se pretende encaixar são de naturezas diversas, podendo envolver práticas e discursos, pessoas e coisas, interesses públicos e privados, hegemonias e minorias, e assim por diante. $\mathrm{O}$ terceiro destaque diz respeito à produção das escalas, um processo jamais estanque, unilateral, desprovido de embates, conflitos, contradições, enfim, de acoplamentos que precisam ser ajustados, mas que por vezes resistem a essa tentativa. Podem-se dizer maravilhas sobre os megaeventos, como no relatório "Brasil Sustentável”, ou dizer o inverso, ao tratar das violações de direitos humanos (ROLNIK, 2011).

Em casos como as Copas do Mundo ou os Jogos Olímpicos, fica patente o fato de os jogos propriamente ditos articularem-se de maneira tal que constituam uma totalidade. Nas fases eliminatórias, organizadas pelas agências continentais, depuram-se os times que participarão da fase derradeira. Essas assemblages ampliadas conectam, desde o princípio, as disputas esportivas ao simbolismo nacional, e a razão não é outra senão agregar escala, para daí amealhar público,

\footnotetext{
${ }^{11}$ Não há como tratar aqui do problema epistemológico, de se realizar etnografia de megaeventos, o qual tive que enfrentar inúmeras vezes ao longo desses anos à medida em que me propus a realização de um projeto de escala nacional com ferramentas artesanais. Para o uso da noção de escala, sugiro os textos clássicos de Tsing (2000) e Marston (2000), a discussão de Cesarino (2014) e, sobretudo, para o uso num contexto etnográfico no qual me inspiro aqui, Simoni (2009). A partir dessas referências, pode-se acessar uma série bem mais extensa de bibliografia sobre o tema.
} 
publicidade e dividendos. Um time de futebol ou mesmo um competidor individual, de qualquer modalidade, torna-se outra coisa que não um simples atleta ao vestir-se com um uniforme que o aproxima dos símbolos nacionais, tornando-se então uma entidade coletiva extraesportiva. Em que pesem os conflitos, FIFA e COI possuem uma expertise nessa modalidade de acoplamento, algo naturalizado pelo público e tido como tradição dos megaeventos (GIGLIO, 2018).

De qualquer sorte, a Copa e as Olimpíadas são competições que precisam de um espaço físico real para acontecer; a realidade que elas produzem, ou o tipo de emoção, se preferirem, vem justamente desses confrontos reais, conquanto eles sejam experienciados como ficção e, do ponto de vista econômico, importe mais alcançar expectadores através de imagens do que deslocar pessoas aos locais dos eventos. Sendo assim, os jogos poderiam acontecer sempre em um mesmo país ou cidade - poder-se-ia criar uma cidade olímpica ou futebolística, como as cidades cinematográficas. Por tradição - razões econômicas e simbólicas inclusas - tanto a FIFA quanto o COI preferem alocar suas assemblages em países e cidades diferentes a cada nova edição. Estabelecer nexos outros que não a simples relação instrumental - do tipo: precisamos que construam a infraestrutura para nosso evento - é essencial para o sucesso do empreendimento. E para serem eficazes nesse processo, a ponto de haver disputas pelas sedes, é fundamental que se construam, desde o ponto de partida, narrativas em escala ampliada, cujo objetivo, primeiro, é a produção do evento como algo extraordinário, uma oportunidade única e imperdível. ${ }^{12}$

Ainda mais susceptível às questões de escala são as agências públicas consorciadas. No caso da Copa de 2014, já discuti em outras oportunidades (DAMO, 2016; DAMO; OLIVEN, 2014) a forma como o Governo Federal assimilou a frente discursiva proposta pela FIFA, nitidamente influenciada pelo marketing da entidade, justificando o empenho para a realização da Copa como uma oportunidade (depois transformada em obrigação) que demandava investimentos (um eufemismo para custos ou gastos), mas geraria legados (a mais etérea das três categorias, pois se alegava que parte deles seriam "intangíveis") como compensação.

Para tornar verossímil a ideia de que a Copa seria um evento da nação - o "Brasil" enquanto uma totalidade - foi necessário disseminar sedes e levantar

\footnotetext{
12 Outras modalidades de megaeventos ou megaempreendimentos demandam estratégias inversas, minimizando ou omitindo seus impactos ou parte deles. Penso, de maneira contrastiva, nos megaempreendimentos com implicações sociais ou ambientais de grande monta e, portanto, tendem a gerar tanto mais controvérsias quanto maior for a publicidade.
} 
estádios economicamente insustentáveis, além de o Estado cumprir exigências contratuais com a FIFA, pois do contrário o país perderia as benesses do mantra marqueteiro veiculado sob o rótulo de soft power (ALMEIDA; GUTIERREZ, 2018). Além de estádios popularmente chamados de "padrão FIFA", Blatter e seus assistentes exigiam o mesmo em relação à mobilidade, hospedagem, segurança, alimentação e conectividade, entre outros. Tais conexões são pensadas para circunscrever o risco dos torcedores visitantes aos jogos e ainda assim a uma experiência mimética; tudo o resto deve ocorrer dentro de um registro de normalidade e de previsibilidade. ${ }^{13}$ Para atender às exigências da FIFA, o governo brasileiro conectou aos estádios obras outras que acarretaram mais dispêndio de recursos públicos, com remoções forçadas e até mudanças de legislação. O resultado foi a produção de um emaranhado que tornou possível a realização dos jogos de forma satisfatória - enquanto um evento esportivo a realização da Copa foi um sucesso - mas deixou inúmeros fios desconectados, que seriam explorados nas manifestações de 2013.

A Copa pode ser considerada um evento extraordinário pela magnitude e pela excepcionalidade, mas não seria um protótipo de evento crítico, no sentido de Das (1995). Não é algo inesperado, nem disruptivo - a única disrupção aceitável é em relação ao resultado dos jogos, mas nesse caso é algo próprio ao ritual e, portanto, previsível. Também é discutível o enquadramento de manifestações políticas nesse rótulo, pois isto seria supor que estas sejam disruptivas, quando o melhor seria pensá-las como atinentes às sociedades democráticas. Contudo, a escala das JsJ é que foi extraordinária e talvez por isso se possa aplicar a noção de evento crítico, tanto mais que não se previa o acoplamento das manifestações insurgentes à Copa das Confederações.

No entanto, foi justamente o encaixe temporal dos dois megaeventos - ou teriam se tornado um só? - o ponto de partida para uma série de questões concernentes às conexões mais sutis. Além da questão temporal, há outros nexos que fizeram com que a festa esperada resultasse nos protestos ocorridos, o que implicou uma dupla mudança de escala. De uma parte, as manifestações dos insurgentes, localizadas em algumas capitais, se nacionalizaram. Isto só foi possível devido à agregação de outros manifestantes, incluindo-se os intransigentes, que alteraram a escala ideológica das pautas. De outra parte, os intransigentes e suas pautas contribuíram decisivamente para acoplar os

\footnotetext{
${ }^{13}$ É um tipo de deslocamento sem a expectativa de sobressaltos - aeroporto, hotel, ponto turístico, comida típica mesclada com cozinha internacional, algum ritual ou espetáculo exótico com o qual se terá um envolvimento distanciado e, claro, a ida aos jogos, razão pela qual os estádios devem estar conformes a esse padrão.
} 
protestos políticos ao evento esportivo, e, ao fazê-lo, não apenas se alterou a escala das manifestações em termos de proporção, mas de sentido, agregando um matiz verde e amarelo até então inexistente.

\section{A nebulosa trama envolvendo as arenas e a emergência da narrativa da corrupção}

Entre uma dezena de rubricas, a remodelação dos estádios seria responsável por aproximadamente $1 / 3$ dos 27 bilhões de reais empenhados pelo Governo Federal na preparação da Copa 2014, segundo levantamento do Tribunal de Contas divulgado em relatório sociotécnico - nos moldes do Brasil Sustentável, da E\&Y/FGV, mas com o propósito de accountability (DAMO, 2016). Esses recursos foram destinados como financiamento - e não doação! - do Banco Nacional de Desenvolvimento (BNDES), sendo que parte deles foi acessado por entes públicos (governos estaduais) e outra por agentes privados (empreiteiras consorciadas com clubes). Mesmo que subsidiado, o dinheiro do BNDES não fugiu aos moldes de outros financiamentos concedidos pelo banco. Do ponto de vista estritamente econômico, não haveria motivos para controvérsias, mas do ponto de vista de uma outra economia, de ordem moral, aquilo que o governo tratava como investimentos, seguindo o discurso da FIFA, transformou-se em gastos no jargão das ruas. E o pior: em gastos injustificáveis.

Ocorre que os estádios constituem um espaço holográfico, pois condensam o "território do torcer", o local de realização dos eventos, da fixação das memórias, das performances exuberantes, das experiências dramáticas, e assim por diante. Inicialmente, a "modernização" dos estádios foi aclamada na mídia esportiva, sendo apresentada como uma das razões que justificavam a realização da Copa no Brasil. Por modernização, no registro êmico, deve-se entender, basicamente, uma modalidade de "europeização", uma vez que o Caderno de Encargos da FIFA, que se ocupava das especificações das arenas, propunha um modelo conhecido como all seat, implementado a partir da Inglaterra na década de 1990, cuja ênfase recai sobre os itens segurança e conforto (MASCARENHAS, 2009; CAMPOS, 2014). A bibliografia tem adotado o neologismo arenização para se referir a esse modelo, que contrasta com seus predecessores, e destacado, entre outros aspectos, seu caráter excludente, seja em relação à diversidade das formas de torcer, seja em relação ao público de baixa renda. ${ }^{14}$

${ }^{14}$ Há extensa bibliografia a esse respeito, entre as quais Duke (1994), Curi (2012), Holanda (2014), Holanda e Medeiros (2019), Mascarenhas (2009), Campos (2016), Bochi (2016), Campos (2014), 
Seguindo-se Ingold (2012), um estádio é algo mais do que uma montanha de concreto, tendo sua vida efetiva - e efervescente - à medida que recebe jogos e, sobretudo, público. Seguindo-se essa orientação, pode-se considerar como natimortas algumas das arenas edificadas para a Copa 2014. A obsolescência (mal)programada de estádios não é novidade no Brasil, pois a Ditadura Militar construiu vários desses exemplares. O mais bizarro deles, talvez, o Colosso da Lagoa, na cidade de Erechim, comportava à época de sua inauguração toda a população da cidade. ${ }^{15}$ Já os casos de obsolescência ocorridos com a Copa 2014 resultam, por um lado, de decisões políticas com fins eleitorais, por outro lado, se assemelham àqueles da Copa de 2006, realizada na África do Sul, e poderiam ser rotuladas como decisões políticas fundamentadas em ilusões econômicas uma delas associada às possibilidades de multiuso, muito propalada à época das edificações, mas cuja gestão tem se revelado problemática.

O exemplo mais eloquente de obsolescência é o Estádio Nacional de Brasília Mané Garrincha, pelas dimensões colossais e pelos custos astronômicos. Embora menores e mais baratos, a Arena Pantanal, localizada em Cuiabá, e a Arena Amazônia, em Manaus, foram dois outros projetos difíceis de justificar. A Arena Pernambuco, localizada em São João da Mata, na Grande Recife, corre o risco de vir a ser contabilizada, no futuro, junto com os outros três estádios já referidos, mas aqui merece um destaque, porque talvez seja o protótipo que melhor ilustra a mistificação exercida pelo marketing da FIFA.

À diferença de Brasília, Cuiabá e Manaus, cujos clubes locais participam, quando muito, da série B do Campeonato Brasileiro, Recife têm três agremiações populares oscilando entre as Séries A e C, além de mobilizarem públicos extensos nos circuitos regionais - estadual e nordestino. Todas as três agremiações possuíam estádios próprios, com fortes vínculos territoriais e afetivos de parte dos seus torcedores. Esse "detalhe" foi ignorado pelo projeto da Arena Pernambuco, cujo governador à época, Eduardo Campos, era entusiasta e avalista. A arena foi edificada seguindo uma tendência europeia que tende a deslocar equipamentos destinados a megaeventos para a periferia das cidades. $\mathrm{O}$ projeto da Arena Pernambuco foi além, apostando todas as fichas no marketing da FIFA ao imaginar que o estádio serviria como âncora para outros empreendimentos: via de regra um shopping, um centro empresarial e um enorme

Oliveira (2017) e Santos (2017).

${ }^{15}$ A construção de estádios era parte da estratégia política da Ditadura, que também havia se imiscuído na gestão do futebol profissional, razão pela qual surgiu o slogan: "onde a Arena vai mal, mais um clube no (campeonato) nacional". Imaginava-se que tais aberrações tivessem ficado no passado, mas não foi o que aconteceu. 
condomínio residencial (NASCIMENTO, 2013). Todavia, o "espírito da copa" não sensibilizou os torcedores do Náutico, o clube destacado para ser o principal usuário da nova arena. De um ponto de vista da economia financeira, o velho estádio dos Aflitos, localizado em bairro nobre de Recife, deveria dar lugar a um shopping de alto padrão, enquanto seus torcedores passariam a ver os jogos na periferia. A crônica esportiva, que em geral reverbera entusiasticamente esses modelos de negócio, envernizados pelo marketing, e o staff do então governador Eduardo Campos julgaram possível construir uma cidade do zero, mas acabaram demonstrando pouca apetência para compreender uma outra modalidade de economia, aquela de ordem afetiva. Passados pouco mais de 5 anos, a resistência em relação à Arena Pernambuco fez com que a direção do Náutico remodelasse o velho Aflitos e a conquista da Série C, em 2019, ganhou o noticiário esportivo nacional, pois os torcedores fizeram uma comemoração à moda antiga, adentrando o gramado depois do jogo para confraternizar com os jogadores, protagonizando uma festa efusiva, banida das novas arenas em versão all seat.

Originalmente, a FIFA sugeriu que fossem usadas entre 8 e 10 sedes, mas por uma decisão do governo brasileiro foram 12. Seguindo-se um critério de sustentabilidade econômica, a Copa ficaria concentrada nas regiões Sudeste, Sul e Nordeste, nesta ordem. Quatro cidades-sedes seriam escolhas óbvias - Rio de Janeiro, São Paulo, Belo Horizonte e Porto Alegre - e outras quatro dificilmente ficariam de fora - Salvador, Recife, Fortaleza e Curitiba. Uma das alegações para estender o número de sedes, ampliando os gastos, foi de que a Copa deveria ser "interiorizada", mas esse argumento é facilmente contestado. Seguindo-se a lógica econômica, as regiões Norte e Centro-Oeste seriam contempladas e a interiorização assegurada, reformando-se o Serra Dourada, em Goiânia, e um dos estádios de Belém, no Pará, ao invés de construir estádios em Brasília, Manaus ou Cuiabá.

Na época da escolha das sedes, em 2009, o governador do Distrito Federal era o encrencado José Roberto Arruda, afastado do cargo por denúncias de corrupção antes do final do mandato. Em 2010, Agnelo Queiróz, então filiado ao PT, venceu as eleições e seguiu o projeto faraônico original, em que pese nas duas últimas décadas nenhum clube do Distrito Federal ter disputado sequer a Série B Nacional. ${ }^{16}$ Goiânia, cuja candidatura foi preterida em 2009, é a capital de um

\footnotetext{
${ }^{16}$ Em 2018 o Ministério Público do Distrito Federal apresentou denúncia à Justiça Federal a partir das investigações da operação Panatenaico, fruto de delações da Andrade Gutiérrez, principal responsável pela execução do Mané Garrincha. Na denúncia estão citados os ex-governadores José Roberto Arruda (2006-10), Agnelo Queiroz (2011-14), e o ex-vice-governador Tadeu Filippelli (201114). Originalmente orçado em 600 milhões, o estádio custou mais de 1,8 bilhão ao governo do Distrito Federal. https://g1.globo.com/df/distrito-federal/noticia/operacao-panatenaico-mpf-denuncia-
} 
Estado que à época era governado por Marconi Perillo, então filiado ao PSDB, principal adversário do PT, e desafeto pessoal do Presidente Lula. Em contrapartida, Blairo Maggi, aliado de Lula desde 2002, governador de Mato Grosso por dois mandatos consecutivos (2002-09) e eleito senador em 2010, teria exercido forte influência na escolha de Cuiabá; assim como Eduardo Braga, outro aliado petista de primeira hora, teria sido decisivo para que Manaus, a capital do Amazonas, da qual era governador e seria mais tarde eleito senador, fosse escolhida como sede. A opção por Natal, em que pese haver dois clubes populares na cidade, também poderia ser agrupada ao bloco das escolhas políticas, como seria pelo menos um outro estádio, a Arena Corinthians, ainda que localizado em São Paulo, um dos principais centros futebolísticos do país.

Mesmo em sedes consideradas escolhas-certas, como Rio de Janeiro e São Paulo, seria contestada a necessidade de se fazer reformas radicais e dispendiosas, como foi o caso do Maracanã, ou de construir um novo estádio, como a Arena Corinthians. No Rio de Janeiro havia sido edificado um novo estádio para os Jogos Pan-americanos, em 2007, mas pesou o argumento de que a Copa tinha de ser no Maracanã, como em 1950. Os escândalos de corrupção, com a condenação do governador de então, Sérgio Cabral, a mais de 200 anos de prisão, parece ser uma pista mais promissora para se chegar às razões efetivas pelas quais o novíssimo estádio Nilton Santos foi preterido e a reforma do Maracanã uma das mais dispendiosas. ${ }^{17}$ Dos estádios cujas reformas partiram praticamente do zero, apenas a Fonte Nova, que havia sido interditada por problemas de segurança, parece se justificar tecnicamente.

Porto Alegre foi uma das poucas sedes em que os critérios técnicos preponderaram, pelo menos no ponto de partida. Tendo em vista o porte da cidade e, sobretudo, o fato de que nela estão sediados dois dos principais clubes nacionais, haveria de se esperar que fosse uma das sedes, como de fato aconteceu. Ademais, tanto o Grêmio como o Inter possuíam estádios privados e, portanto, os gastos com reformas teriam de ser bancados pelos clubes, razoável para um país em que prepondera a lógica capitalista. Numa primeira vistoria, realizada ainda em 2007, o Estádio Olímpico foi descartado, mas o Grêmio tratou de se

12-por-superfaturamento-do-mane-garrincha.ghtm

17 " [...] Além das altas exigências da FFIFA para o estádio que sediou a final, a construção também sofreu com desvios e superfaturamentos, chegando a uma soma final de $R \$ 1,2$ bilhão - $R \$ 495$ milhões a mais do que o previsto inicialmente. Disso, o TCE (Tribunal de Contas do Estado do RJ) avalia que R\$ 211 milhões tenham sido superfaturados. A reforma do estádio seria suficiente para manter o Museu Nacional por 2.400 anos (...). Disponível em: https://www.uol.com.br/tilt/ultimasnoticias/redacao/2018/09/04/reforma-do-maracana-cobriria-24-mil-anos-de-orcamento-domuseu-nacional.htm?cmpid=copiaecola. Acesso em: 30 out. 2019. 
beneficiar do crédito junto ao BNDES, fazendo uma parceria com a empreiteira OAS, que participaria da construção de outros estádios, a Arena das Dunas (Natal) e a Fonte Nova (Salvador), esta última em parceria com Odebrecht. Beneficiando-se de benesses do poder público local - como agilização de licenças e mudanças pontuais de legislação, como foi a permuta do terreno onde seria construída a Arena - a OAS colocou o estádio à disposição do Grêmio no final de 2012, antes de todas as demais construções em curso.

Vale a pena referir a construção da Arena do Grêmio - em tempo recorde e com ônus privado, ainda que com financiamento público -, porque mostra como havia alternativas que não implicassem aportes diretos de recursos públicos, como ocorreu com a maioria dos estádios, em particular aqueles bancados por governos estaduais: todos à exceção do Beira-Rio (Internacional), da Arena da Baixada (Atlético Paranaense) e da Arena Corinthians. Isso não impediu que as referências aos gastos com os estádios fossem direcionadas contra o Governo Federal, quando deveriam ter visado aos governos estaduais, se considerar que seriam eles os responsáveis por saldar os empréstimos junto ao BNDES. Exigir coerência de protestos é complicado, mas deve-se destacar que nenhuma das tantas manifestações ocorridas em Porto Alegre ao longo de 2013 e 2014 rumou em direção aos estádios - vale o mesmo para Curitiba.

Todavia, mesmo nas obras privadas, houve a necessidade de intervenções políticas, como no caso do Beira-Rio, que por pouco não foi descredenciado pela FIFA, tendo a presidente Dilma intercedido para que a Andrades Gutierrez fornecesse as garantias necessárias à liberação do financiamento junto ao BNDES. Um impasse ocorreu quando a Andrade Gutierrez pretendeu que o Banrisul um banco estatal - oferecesse tais garantias, um absurdo na medida em que o banco figurava apenas como um intermediário, no caso um repassador dos recursos. A empreiteira chegou a divulgar uma nota pública culpabilizando o Banrisul pelo atraso no cronograma das obras, mas acabou desmentida e criticada por má fé. O caso é emblemático, porque revela o modus operandi do capitalismo brasileiro, sedento por benesses do Estado e avesso ao risco. A reforma do Beira-Rio, entre todos os estádios, foi a que teve menor presença estatal e, no entanto, foi uma das mais morosas, e o estádio deixou de ser sede da Copa das Confederações. Quem credita os problemas de gestão ao Estado teve aí uma prova em contrário, pois, não fosse a interferência da presidente Dilma que além de colorada é mineira, como a Andrade Gutierrez - os jogos da Copa teriam sido realizados na Arena.

Em se tratando de interferências pessoais de gestores públicos, nada se compara à Arena Corinthians, a mais rumorosa das obras, cujas controvérsias 
entre o clube e a Caixa Econômica Federal persistem após sete anos desde a inauguração. Na origem, o Morumbi fora selecionado pela FIFA para sediar os jogos na capital paulista, incluindo-se a abertura. A certa altura surgiu a informação de que havia outro projeto em curso, tramado entre políticos incluindo-se o então prefeito de São Paulo Gilberto Kassab e o presidente Lula, aliados na ocasião (DAMO; OLIVEN, 2014, p. 140-50). A notícia divulgada originalmente pelo jornalista Juca Kfouri só não se confirmou integralmente porque o local anunciado, no bairro de Pirituba, acabou sendo transferido para Itaquera, na zona Leste de São Paulo, reduto de torcedores corinthianos. Sendo Lula um torcedor fanático do Corinthians, era esperado que fosse objeto de críticas, tanto mais que as especulações davam conta da sua efetiva participação na trama. Contudo, houvesse a arena sido um presente de Lula ao Corinthians, como se espalhou pelas redes sociais, o clube não estaria empenhado com a Caixa Econômica até o presente. Ocorre que entre a trama complexa de bastidores, que jamais veio a público inteiramente, e a tese pronta segundo a qual todos os políticos são corruptos, não resta dúvidas quanto àquela que haveria de prevalecer.

Ainda em 2014, apresentamos um panorama com as arenas em reforma e/ou construção e as empreiteiras responsáveis, acrescendo, em nota, que boa parte delas figurava entre os principais agentes privados financiadores de campanhas eleitorais (DAMO; OLIVEN, 2014, p. 151-61). Essa rotina era seguida também por empresas de outros setores - notadamente o financeiro -, cuja estratégia consistia em "doações" a partidos de diferentes matizes, com preferência para os mais "liberais" e, notadamente, para os que se mostrassem mais competitivos. Odebrecht, OAS, Andrade Gutierrez, entre outras, destacavam-se tanto nas "doações eleitorais" quanto nas obras da Copa 2014, além de estarem se preparando para administrar as novas arenas que não tivessem sido alcançadas pela Operação Lava-Jato. ${ }^{18}$

Não obstante o fato de que alguns dirigentes de clubes e de federações tenham uma carreira política convencional, por vezes impulsionada pela gestão no futebol, de modo geral eles não desfrutam de boa reputação. Seriam esses agentes que o poder público teria como parceiros na organização da Copa, incluindo-se aqueles do mais alto escalão. À época em que a Copa de 2014 foi destinada ao

\footnotetext{
18 Já são tantas as controvérsias em torno dessa operação do Ministério Público Federal que existe um verbete específico a respeito na Wikipédia, e elas seguem sendo publicizadas, com revelações que vão de encontro ao tom apologético que prevaleceu entre 2014 e 2018. Disponível em: https://pt.wikipedia.org/wiki/Controv\%C3\%A9rsias_envolvendo_a_Opera\%C3\%A7\%C3\%A3o_L ava_Jato. Acesso em: 15 nov. 2019.
} 
Brasil, em 2007, Joseph Blatter ainda era o todo poderoso chefe da FIFA, organização que se locupletava de ter mais filiados do que a ONU. Os protestos de 2013 fizeram mal à reputação de Blatter e Jérôme Valck, seu escudeiro, mas antes disso ele já andava encrencado. Ainda em 2011 foi traduzido para o português o livro "Jogo Sujo - o mundo secreto da FIFA", do jornalista inglês Andrew Jennings, no qual são discutidos vários casos envolvendo corrupção na FIFA. ${ }^{19}$ Ricardo Teixeira, que entre outras bravatas chegou a dizer que a Copa de 2014 ficaria conhecida como "a Copa da iniciativa privada", já havia sido objeto de uma CPI, no final dos anos de 1990 (REBELO; TORRES, 2001). Ele renunciou, em 2012, à presidência da CBF, após 23 anos, e ao comando do Comitê Local da Copa, sob ameaças de investigação, e foi banido do futebol pela FIFA em 2019. José Maria Marins, herdeiro de Teixeira e presidente da CBF à época da realização da Copa 2014, foi preso em Zurique, em 2015.

Dirigentes de futebol de péssima reputação, empreiteiras suspeitas de enriquecimento com obras públicas e um governo de coalização heterodoxa haviam se tornado parceiros na consecução de obras de enorme repercussão midiática. Tivesse sido o chefe da coalisão um partido de centro ou de centro direita, provavelmente teria havido críticas mais contundentes antes mesmo do anúncio do Brasil como sede. As esquerdas em geral são avessas aos megaeventos esportivos, mas estando o PT na presidência, houve um certo silenciamento com relação a arranjos tão heterodoxos. Havia críticas contundentes, que partiam da oposição ao governo Lula, cujos expoentes pertenciam a partidos que tinham escassa credibilidade para exigir transparência. Ou eram veiculadas por movimentos sociais com pouca influência junto à opinião pública, em que pese fossem aguerridos.

À medida que os estádios foram sendo inaugurados, as críticas adquiriram tração e o que se viu não foi uma lenta escalada das contestações, antes uma explosão; um jorro abrupto que lembra as iradas manifestações de torcedores. As JsJ não principiaram no entorno dos estádios, nem foram capitaneadas pelos Comitês Populares da Copa. Havia múltiplas pautas nas ruas e nas redes sociais, sendo a contestação à Copa, aparentemente, mais uma delas - é assim que boa parte da bibliografia trata as JsJ. Todavia, existia uma narrativa sendo construída acerca do modo como a Copa estava sendo gestada, e ela envolvia mais do que a apologia aos estádios modernos, às oportunidades e legados imaginados; ela suscitava a hipótese da corrupção, quer fosse por conta dos discursos oportunistas da oposição - e aqui se poderia incluir uma parte da mídia

${ }^{19}$ Blatter foi suspenso em 2015 por 8 anos (CHADE, 2015) e Valcke por 10 anos, em 2018. 
convencional - quer por razões de quem não estava interessado em desgastar o Governo Federal, mas tampouco consentia com a heterodoxia das negociações. De outra parte, havia expectativas e ilusões de que as novas arenas contemplariam cidadãos de todas as classes sociais, como os velhos estádios, que tinham camarotes e cadeiras, mas também arquibancadas e gerais.

Houve um momento, e eu suponho que ele tenha coincidido com a aproximação da Copa das Confederações, em que a população de baixa renda incluindo-se a dita "nova classe média" - se deu conta de que veria a copa 2014 pela televisão, como sempre fizera, pois os estádios não tinham sido projetados para elas, antes para os turistas de ocasião e os brasileiros mais endinheirados. Essas pessoas que se sentiram excluídas não saíram às ruas para protestar, nem esse tipo pontual de desapontamento teve grande destaque nas JsJ. Todavia, a população de baixa renda empenhou seu apoio aos protestos, porque se sentiu alijada da festa. Os movimentos sociais acertaram no alvo com o slogan "Copa para quem?", pois as novas arenas, cujos brasileiros sabiam da existência, ao menos pelo noticiário, foram como que trazidas da ficção à realidade, sendo os cidadãos suscitados a refletir sobre a exclusão dos estádios e de outros serviços públicos.

\section{Misturados, mas não juntos}

Tentarei fazer um bom uso da noção de escala para avaliar as diferentes intensidades das manifestações e captar suas diferenças em termos de horizontes discursivos. Tais distinções são fulcrais para compreender o momentum em que o discurso anticorrupção é encaixado nos protestos dos insurgentes, produzindo não apenas a torção ideológica sugerida no início do texto, senão a eclosão das próprias JsJ. Além das JsJ, portanto, há que se considerar os protestos que as antecederam; os que a sucederam, depois de junho e julho de 2013 e nos primórdios de 2014; e a série iniciada em fins de 2014, contestando o pleito que reelegeu Dilma Rousseff, que prosseguiu com a bandeira do impeachment, da Lava-Jato, da militarização, da Escola sem Partido, entre outras pautas - nem sempre conectadas - propostas por grupos de intransigentes, . Há razões metodológicas implicadas nessas marcações de escalas e, embora não seja possível se ater a cada uma delas, uma breve referência é fundamental, especialmente em relação às que precederam e sucederam às JsJ, que correspondem à ascensão e ocaso dos insurgentes.

Para evitar um retorno ad infinitum no que seriam as origens da JsJ, seguidamente veiculadas à fundação do Movimento Passe Livre em 2005, 
acompanho parte da bibliografia que aponta ao menos duas mobilizações massivas ocorridas em 2013 antes das JsJ, uma delas em Porto Alegre, à qual darei prioridade aqui, e outra em Goiânia. ${ }^{20}$ Esses dois eventos são essenciais do ponto de vista metodológico, pois permitem visualizar os protestos dos grupos insurgentes, e de como eles já haviam extrapolado a pauta dos "vinte centavos". Quando as manifestações emergiram em São Paulo, que para uma parte da bibliografia é o ponto zero das JsJ, as pautas já eram plurais, embora possuíssem uma linha de coerência, porque atinentes aos grupos insurgentes, apenas.

Depois das JsJ houve vários eventos insurgentes dispersos, ainda que recorrentes, em diversas capitais das regiões Sul, Sudeste e no Distrito Federal, ainda ao longo de 2013, e uma tentativa malsucedida de retomá-los, em 2014. Já em fins de 2014, logo após a concorrida reeleição de Dilma Rousseff, iniciou-se um novo ciclo de protestos, cuja escala crescente culminou com o impeachment da presidente em maio de 2016. Disso não tratarei aqui, mas preciso indicar, como quase toda a bibliografia, que essa nova escala de protestos, organizados por grupos aqui chamados de intransigentes, tem relação com as JsJ. Por hora, a "greve dos caminhoneiros", a meu ver a mais intransigente e indiscutivelmente a mais consequente de todas as manifestações, em que pese não tenha havido conflitos e tampouco repressão, encerra, por hora, a escalada desse ciclo de manifestações públicas.

Recuperar as manifestações de Porto Alegre não implica apenas o reestabelecimento de uma ordem cronológica, antes uma estratégia comparativa. É consensual entre a bibliografia que as JsJ principiaram na primeira semana de junho, em São Paulo, lideradas pelo Movimento Passe Livre (MPL), tendo como mote a contrariedade ao aumento de $\mathrm{R} \$ 0,20$ anunciado pelo prefeito petista Fernando Haddad. Quando as JsJ são confrontadas com as Jornadas do Bloco de Lutas (JsBLs), percebe-se, entre outras diferenças, que estas possuíam uma orientação ideológica mais coesa em termos de pautas e de ações. As JsBLs foram articuladas por coletivos de esquerda; à "esquerda do PT", por assim dizer, pois se destacavam militantes do PSOL, do PSTU, do PCO e ativistas sem vinculação partidária, com destaque para coletivos como o Defesa Pública da Alegria (artistas de rua/amadores) e o Massa Crítica (cicloativistas), entre outros. Havia também militantes do PT e do PCdoB, que acabaram expurgados do Bloco de Lutas no decorrer da JsJ, mas o destaque tanto na condução do Bloco quanto nas ações de rua deve ser dado aos anarquistas, que lograram imprimir suas marcas

${ }^{20}$ Para uma abordagem das "jornadas de maio", ocorridas em Goiânia e orientadas pela Frente de Luta do Transporte Público (FLTP), incluindo-se uma crítica à interpretação "sudestecêntrica" das JsJ, conferir Tavares, Roriz e Oliveira (2016). 
melhor do que qualquer outro segmento de militantes (MORAES; VIEIRA, 2017; GONÇALVES, 2019).

A repressão desproporcional de que foram vítimas os ativistas que tentaram esvaziar Fuleco, o mascote da Copa, instalado na área central de Porto Alegre em outubro de 2012, pareceu, em princípio, um evento isolado e despretencioso. O Largo Glênio Peres, em frente ao Mercado Público e ao lado da Prefeitura, era um local de confraternização de ativistas dos mais variados matizes, cujas ações incluíam debates informais, performances teatrais, comercialização de cerveja artesanal e consumo de comida vegana. Havia um debate bem alinhado entre esses grupos no sentido de ocupação dos espaços públicos, mas a abordagem ao Fuleco não fora programada - ele simplesmente apareceu naquele espaço, com propaganda explícita da Cola-Cola, uma das patrocinadoras da Copa. Para vários militantes que seriam ouvidos mais tarde, ${ }^{21}$ a repressão desproporcional na ocasião teria sido decisiva para a formação do Bloco de Lutas, a coalisão responsável por dar tração e direção aos protestos protocolares de secundaristas que normalmente ocorrem quando do anúncio anual do aumento do transporte público. Ao longo dos meses de março e abril de 2013, o Bloco de Lutas orientou as manifestações pelas principais ruas do Centro Histórico e adjacências, mesmo depois que uma liminar suspendeu temporariamente o aumento de 20 centavos. Foi desse contexto que surgiu o slogan, amplamente disseminado nas JsJ, de que a luta não era apenas pelos 20 centavos. ${ }^{22}$

Diversas pesquisas que acompanharam as manifestações de 2013 desde o período de gestação ou que se preocuparam em ouvir suas lideranças - mesmo que, oficialmente, houvesse um esforço para negar tal existência - dão conta de um ambiente de insurgência, especialmente entre os anarquistas, entre os quais se partilhava a sensação de que "algo estava por acontecer" (GONÇALVES, 2019; MENDONÇA, 2018). Esse "imaginário insurgente" era um compósito inspirado em eventos próximos no tempo, mas distante no espaço, como a Ocuppy Wall Street, Os Indignados e a Primavera Árabe, mas também por eventos distantes no tempo e no espaço, como Maio de 1968 e até a Queda da Bastilha - ao menos para os anarquistas esse é um evento histórico-mítico seguidamente atualizado -; ou ainda, por eventos deslocados do tempo e do espaço histórico, como o filme de James McTeigue, "V de Vingança".

Não havia razões econômicas ou políticas pontuais que ensejassem um levante qualquer. A imaginação insurgente aflorada, combinada à repressão

${ }^{21}$ Sobre o esvaziamento do Fuleco conferir Haubrich (2018, p. 32-3), Gonçalves (2019, p. 98) e DaSilva (2016, p. 57ss), esta última com imagens.

${ }^{22}$ Coincidentemente, o valor do aumento contestado em São Paulo também era de 20 centavos. 
policial - no caso de Porto Alegre, no episódio do Fuleco ${ }^{23}$-, suscitou a disposição para a rebelião; um cenário politicamente difuso, mas esteticamente excitante e envolvente. O Bloco de Lutas saiu da imaginação para a realidade, através de assembleias reunindo coletivos de matizes diversificadas, e, em seguida, adensou a mobilização contra o aumento das passagens, de forma que os estudantes secundaristas, que protestam regular e protocolarmente - quase que burocraticamente - contra tais aumentos, apresentaram-se às ruas em março de 2013 em maior número, mais bem articulados e mais sofisticados em termos de repertórios de ação. O Bloco orientou as manifestações em Porto Alegre que, exitosas, contribuíram não apenas para forçar uma liminar que suspendeu o aumento, mas para mostrar a outras cidades que os protestos poderiam ser efetivos, enquanto as redes sociais mostrariam o quão excitantes eles poderiam ser. As JsBLs transformaram a sensação de que alguma coisas grandiosa estava por acontecer em algo possível de fazer acontecer, razão pela qual os protestos permaneceram intensos mesmo depois de sustado o aumento, explicitando a disposição de lutar por algo além da redução da tarifa do transporte coletivo "não são apenas pelos 20 centavos", diziam os manifestantes.

A estratégia da presidência da República de demandar à prefeitura de São Paulo a protelação do reajuste das passagens, de março para junho, não surtiu o efeito esperado. Por um lado, a inflação continuou em alta, prenunciando uma crise fiscal que teria de ser enfrentada a partir de 2014, e cujo resultado foi catastrófico, pois criou uma tensão entre a presidência da República e sua base de apoio parlamentar. Por outro lado, realocou, por assim dizer, o calendário dos protestos, aproximando-os do início da Copa da Confederações. O governo Dilma supunha que o deslocamento do reajuste arrefecesse os ânimos dos ativistas, confiando nos seus altos índices de popularidade e nas diversas políticas públicas destinadas às classes trabalhadoras, incluindo-se as camadas juvenis, favorecidas pela expansão da oferta de vagas em universidades públicas - com programas de ações afirmativas - e privadas, além do programa SemFronteiras, que possibilitava o intercâmbio internacional de estudantes de baixa renda. Ao que tudo indica, nem de longe o governo imaginou que a Copa das Confederações pudesse resultar em outra coisa que não uma festa.

Em Porto Alegre a mobilização de março e abril havia se dissipado, mas a sua memória ainda estava presente em junho. No Rio de Janeiro, onde havia uma mobilização mais bem articulada contra os megaeventos, com embates renitentes contra as desocupações (MAGALHÃES, 2013; 2019), incluindo-se uma

\footnotetext{
${ }^{23}$ Note-se que, tanto aqui quanto em São Paulo, a repressão policial desempenha um papel decisivo no sentido inverso do pretendido, aguçando a revolta, a resistência e a extensão dos protestos.
} 
resistência performática junto ao Museu do Índio, também houve alteração no calendário do reajuste das passagens escolares, de março para julho. Brasília era outra cidade com potencial para protestos de rua, mas foi em São Paulo, sob o protagonismo do MPL, que os protestos adquiriram consistência, sobretudo depois da intensa repressão policial em 13 de junho (BEZERRA; GRILLO, 2014; D'ANDREA, 2014; ORTELLADO, 2013). Ao invés de a violência policial refrear a disposição dos militantes, ela a potencializou, pois entre os intransigentes havia muitos anarquistas e para estes a violenta reação estatal era tida como prova de que o sistema estava sendo atingido e a contestação deveria ser intensificada, pois se encontrava no caminho certo. Fazendo uso ostensivo e indiscriminado de balas de borracha e gás de pimenta, a polícia atingiu manifestantes de forma indiscriminada e até profissionais da mídia, aumentando a repercussão e suscitando contestações para além dos grupos que estavam diretamente implicados. Em todo o caso, até esse momento, tínhamos nas ruas apenas militantes e ativistas insurgentes.

Como nos advertem tantos experts no assunto, entre os quais Tambiah (1997), os rituais são essenciais para se compreender a política, tanto mais quando se trata de megaprotestos. Parafraseando Schechner (2011, p. 218), outro especialista em rituais e performances, se há um momento em que as JsJ decolam, ele está vinculado ao cenário de abertura da Copa das Confederações, no dia 15 de junho. Ao serem apresentados pelo locutor do Estádio Nacional de Brasília, Joseph Blatter e Dilma Roussef foram ruidosamente vaiados. ${ }^{24}$ Algo parecido, senão pior, já havia ocorrido a Blatter em Seul, em 2002 (JENNINGS, 2011, p. 193ss), assim como a Lula, quando da abertura dos Jogos Pan-Americanos, em 2007, no Rio de Janeiro. Na transmissão da TV Globo, o narrador Galvão Bueno tentou contornar o mal-estar, afirmando que "[...] na democracia em que vivemos é um direito absoluto do povo [apupar as autoridades] [...]". Já Blatter, mantendo a postura arrogante de outras ocasiões, repreendeu o público no melhor estilo colonizador: "Amigos do futebol brasileiro, onde estão o respeito e o fair-play, por favor!?" O público, como seria de esperar, reagiu intensificando as vaias. Dilma, ainda mais sisuda do que o habitual, fez uma declaração peremptória, em meio ao ruído dos torcedores: "declaro oficialmente aberta a Copa das Confederações FIFA 2013". E mais não disse, imaginado, talvez, que estivesse no lugar errado, acompanhada de um inconveniente ${ }^{25}$ para cumprir um protocolo indesejado.

\footnotetext{
${ }^{24}$ Disponível em: http:/ / globoesporte.globo.com/futebol/selecao-brasileira/ noticia/2013/06/dilma-e-blatter-saovaiados-em-abertura-da-copa-das-confederacoes.html. Acesso em: 10 nov. 2010.

${ }^{25}$ A duras penas Dilma havia se livrado da presença de José Maria Marins no cerimonial, o então
} 
A cena de Dilma e Blatter sendo vaiados se tornaria icônica; ela selaria, antes mesmo do início da Copa, a impossibilidade de seu uso eleitoral, como comprovaria a campanha à reeleição no ano seguinte. O discurso dos legados, incluindo-se o intangível, desandara como um pudim tirado quente da forma. Do lado de fora dos estádios havia manifestações hostis de grupos insurgentes, representando a vontade dos excluídos e reivindicando "hospitais e escolas "padrão FIFA'". No interior deles, uma multidão que usava escolas e hospitais privados e desejava estádios seguros e higienizados, mas paradoxalmente, agora que os tinha, mostrava-se ainda mais arredia, deselegante e até grosseira nas suas interpelações ${ }^{26}$ Não sobrou uma viva alma para fazer a defesa da trilogia oportunidade-investimento-legado, quanto menos entre a oportunista crônica esportiva.

Na semana subsequente, entre os dias 17 e 22 - com um pico entre os dias 19 e 21 (MARENCO, 2014) - surgiram tantas pessoas nas ruas que suscitaram na crônica a lembrança das grandes rebeliões públicas: Primavera Árabe, Indignados, Caras Pintadas, Diretas Já, Maio de 98, entre outras. Jornalistas que até então tratavam os manifestantes como baderneiros passaram a exaltá-los, e a Rede Globo chegou a cancelar a programação em horário nobre no dia 20 de junho para transmitir ao vivo os protestos de rua. ${ }^{27}$ Cidades de pequeno e médio portes, que normalmente assistem às manifestações pelo noticiário, tiveram a oportunidade de sair às ruas, convocadas pelas redes sociais - Twitter e Facebook - portando cartazes individuais com toda a sorte de reivindicações, mas as cores haviam mudado. Se até então predominavam o vermelho e o preto, a partir de 15 de junho as ruas se tornaram verdes e amarelas, como se fossem uma extensão dos estádios. Nas grandes cidades as performances Black Bloc encontraram o cenário perfeito à realização, com ataques ao patrimônio público e privado. ${ }^{28} \mathrm{O}$

presidente da $\mathrm{CBF}$, um coronel do exército simpático à Ditadura Militar pela qual a presidente fora torturada.

${ }^{26}$ Sobre as manifestações contra Dilma Rousseff na final da Copa publiquei um texto no site Ludopédio "A Tragédia de 2014". Disponível em: https://www.ludopedio.com.br/arquibancada/ tragedia-de-2014/?doing_wp_cron=1576721299.9711709022521972656250

${ }^{27}$ Analisando algumas dezenas de textos contemporâneos em que a "torção ideológica" é mencionada - se não com este termo, com qualquer outro insinuando uma mudança de perspectiva - aparece com notável frequência duas crônicas antitéticas de Arnaldo Jabor, veiculadas pela Rede Globo. Em alguns desses textos as crônicas são indícios da mudança de postura da grande mídia, com o que eu concordo, mas outros tomam a segunda intervenção, estimulando as manifestações como responsáveis pela virada, do que eu discordo.

${ }^{28}$ A certa altura a abordagem saiu do controle, havendo depredações indiscriminadas - sinalizações de trânsito, lixeiras, bancas de revistas, quiosques, etc. - e surgiram até grupos de saqueadores oportunistas (GONÇALVES, 2019). 
MPL tornara-se uma voz difusa, entre outras; até mesmo o Bloco de Lutas, hegemônico em Porto Alegre nos meses de março e abril, acabara ofuscado em junho, quando as manifestações retornaram. A orientação das ruas estava pulverizada, e os próprios significados dos protestos entraram em disputa, predominando entre as ciências sociais interpretações otimistas, que saudavam a renovação da democracia, a retomada das ruas e a voz do povo e da juventude a reorientar a política.

Poucos ousaram pensar noutros desdobramentos possíveis. Num texto para uma coletânea organizada às pressas, concluí minha participação em forma de pergunta - "Tanto barulho por nada?" -, desconfiado de que a agitação e a euforia tinham perdido fôlego rapidamente, corroborando a interpretação de que as JsJ tinham sido uma espécie de communitas - um movimento político com destacado componente estético; não no sentido de beleza, propriamente, mas de excitação, imaginação, aventura e celebração da democracia, embora ela fosse também uma vilã dos protestos. ${ }^{29} \mathrm{Um}$ tanto pressionado pelo entusiasmo do entorno, fechei a publicação de maneira cautelosa, afirmado que as manifestações haviam contribuído para a consolidação e o aprimoramento da democracia (DAMO, 2014). ${ }^{30}$ Das dezenas de textos que li desse período, Marenco (2014) foi um dos que acertou no ponto, ao chamar a atenção para o fato de que pouco mais de um mês depois de Maio de 1968, quando ao menos na França a "imaginação chegou ao poder", a direita obteve expressiva vitória nas urnas liderada pelo General De Gaulle.

Mal comparando-se as JsJ com Maio de 68, é preciso destacar que na França a reação veio a posteriori, tendo as manifestações de Maio mantido a hegemonia esquerdista, muito diferente do que se passou no Brasil, em que a torção ideológica ocorreu no decurso mesmo das manifestações. Analisando notícias e editorias da "grande imprensa", publicadas antes, durante e depois do pico dos protestos, Melo e Vaz (2018) identificam nesse período a "mudança" - que aqui chamo de torção, pois há disputas de narrativas e de espaços, on-line e nas ruas e apontam dois eixos principais que norteavam as críticas ao Estado no material analisado: a violência policial e o discurso anticorrupção.

A questão da violência não pode ser aqui debatida, dada a complexidade que

\footnotetext{
${ }^{29}$ Em 2014 fui convidado a fazer uma publicação destinada ao público ampliado no Boletim da ABA, e na ocasião me senti tentado, em que pese o risco de ser acusado de reacionário, de apontar certos pontos de encontro entre extremos que haviam estado nas ruas em 2013, anarquistas e anarcocapitalistas. Duvido que o texto tenha despertado interesse, mas ele para em pé 5 anos depois.

${ }^{30}$ Uma colega que lera o texto original havia dito que eu estava dando demasiada ênfase aos aspectos estéticos e desdenhando os componentes políticos; uma interpretação a seus olhos conservadora, senão reacionária.
} 
ela suscita. ${ }^{31} \mathrm{Na}$ medida em que os episódios de repressão se concentraram, basicamente, nas grandes capitais, e considerando-se que as JsJ aconteceram em centenas de cidades, tudo leva a crer que foi o discurso anticorrupção que alimentou o crescimento exponencial dos protestos. Por essa razão, faz todo o sentido a questão formulada por Melo e Vaz (2018): "como a corrupção coube numa mobilização que lutava contra o aumento de passagem?" A propósito, este é um dos raros textos de fora do campo dos "estudos esportivos", que leva efetivamente a sério o impacto da Copa ou, preferindo-se, de como a participação do Estado na sua organização possibilitou a construção de um discurso midiático que permitiria, ao mesmo tempo, ser facilmente assimilado pelo espectro mais amplo da população e, simultaneamente, conectá-lo ao governo do PT. Os heterodoxos critérios que orientaram o governo no decurso da reforma e a construção de estádios - desde a concepção dos projetos à consecução dos mesmos, passando pelas alianças políticas - exerceram um efeito holográfico, contaminando a participação do governo na organização dos megaeventos em sua totalidade. Não foram suficientes as vaias a Dilma e Blatter; desejava-se mais, sobretudo de parte dos intransigentes, que havia tempos ameaçavam sem sucesso protestos de rua. As portentosas arenas financiadas e/ou edificadas com recursos públicos serviram de pretexto para a exorcização de uma série extensa de críticas ao petismo, na época há mais de uma década à frente da coalisão governista. Em que pese a diversidade sempre destacada das JsJ, é a crítica ao Estado e sua gestão que acopla as pautas insurgentes e intransigentes, com notável e talvez inesperado êxito para estes últimos.

A escala das manifestações decresceu lentamente depois do dia 21 de junho e quando da final da Copa das Confederações, no dia 30, restavam praticamente apenas insurgentes nas ruas - os intransigentes estavam curtindo os jogos nos estádios ou em suas casas. Em julho ainda houve algumas chamadas para protestos e até a velha guarda, composta por sindicalistas, chegou a esboçar uma greve à sua maneira, em meados de julho. Mesmo nas capitais das regiões Sul, Sudeste e Brasília, onde seguiram ocorrendo manifestações e enfrentamentos com a polícia, estas se tornaram menos frequentes. A ocupação da Câmara de

\footnotetext{
${ }^{31}$ Há que se analisar, inclusive, o tanto que a violência policial contribuiu para justificar a performance Black Bloc. Além da truculência policial criticada em quase todos os textos, incluindo-se todas as modalidades de excessos, há que se considerar o fato de que a ação policial também, dependendo da gradação, pode contribuir para incrementar os protestos, tornando-os mais intensos, espetaculares e excitantes, pelo menos para uma parte dos manifestantes. Há, portanto, que se observar criteriosamente essa questão, considerando-se, entre outros aspectos, que ao menos nas grandes cidades as JsJ ocorreram no período noturno, imiscuindo ainda mais a estética (associada à sociabilidade e à confraternização) e a política.
} 
vereadores de Porto Alegre pelo Bloco de Lutas (SEGARRA, 2015) e a Ocupa Cabral (BORGES, 2017), no Rio de Janeiro, seguiram alimentando o imaginário insurgente, mas ao menos no caso porto-alegrense, à ousada ocupação também correspondeu, paradoxalmente, o ocaso do Bloco de Lutas, corroído por tensões internas e pelo ímpeto purificador a que são sujeitas também as seitas religiosas (MUHALE, 2014).

Algumas estratégias contribuíram para que em 2014 não se repetissem as JsJ. Seguindo orientações do Palácio do Planalto, PT e PCdoB trataram de acalmar seus quadros, até onde fosse possível, fazendo-os perceber que a reedição dos protestos durante a Copa arruinaria de vez as pretensões de reeleição de Dilma Rousseff. Movimentos liberais, de direita ou antipetistas, aqui tratados como intransigentes, que haviam debutado nas JsJ ou sido criados no decurso dela, mantiveram-se afastados das ruas, embora ativos nas redes sociais, onde de fato se moviam com mais facilidade. PSOL, PSTU e anarquistas das mais diversas filiações, além de movimentos locais, por vezes com a participação de alguma categoria profissional em greve, mantiveram-se nas ruas, mas o fluxo minguante de ativistas e a repressão constante da polícia nas ruas e da opinião pública conservadora nos grandes veículos de comunicação impediram que o ímpeto do ano anterior fosse retomado. A morte de um cinegrafista no Rio de Janeiro, atingido por um rojão durante uma manifestação, contribuiu para afastar ainda mais as pessoas das ruas, aumentar a repressão - agora justificada frente à opinião pública - e reativar o rótulo de baderneiros aos insurgentes.

Um dos slogans de ótima repercussão em 2013: "Copa para quem?", foi reelaborado e radicalizado: "Sem direitos, não vai ter Copa" ou, na versão mais frequente, "não vai ter Copa". Acompanhando desde o início do ano os protestos, podia-se notar a dificuldade de fazê-los adquirir tração e escala nacional. Além dos fatores já referidos, pelo menos em Porto Alegre havia dois outros indicativos de que não teríamos durante a Copa propriamente dita nada próximo do que fora a Copa das Confederações. Um deles eram as tensões internas ao Bloco de Lutas, que haviam começado a desgastá-lo ainda durante as JsJ. O outro era a impopularidade dos protestos frente aos cidadãos comuns, um sinal de que a demonização dos movimentos sociais havia sido eficaz ou de que a reedição interminável de atos sem um foco objetivo, quanto menos resultados palpáveis, só contemplava o gosto de uma fração restrita de militantes. Como registrado na etnografia de Barbieri (2015), em dada ocasião em que a marcha seguiu pelas ruas centrais de Porto Alegre, os manifestantes tiverem de se proteger debaixo das marquises devido ao arremesso de objetos por parte da população civil, além de ouvirem xingamentos e impropérios de toda a ordem. 
Era um indicativo, ainda tênue, de que o refluxo ou os desdobramentos das JsJ seriam de matiz conservadora.

No dia da abertura da Copa, acompanhei em Porto Alegre a chamada de um grupo de coletivos para uma manifestação que partiria do Centro Histórico em direção à FanFest, onde se concentrava a programação oficial do evento. Havia em torno de 3 mil manifestantes, se tanto, identificados com coletivos de partidos como o PSTU e o PSOL, anarquistas de diferentes coletivos, do Comitê Popular da Copa, entre outros. A menos de um terço do deslocamento programado, ativistas sem qualquer identificação tomaram a dianteira da marcha e passaram a depredar placas de rua, de trânsito e lixeiras. Tão logo foi possível tomar uma rua alternativa, os manifestantes identificados com partidos simplesmente abandonaram a marcha, seguindo em direção à Cidade Baixa. A intenção não era alcançar o bairro caracterizado pela boemia, mas expressar a discordância em relação à performance mais agressiva dos Black Blocs - na ocasião, as performances se pareciam mesmo com vandalismo. Desprotegidos pela massa, esse grupo de Black Blocs - ou de vândalos - acabou se deparando com a polícia, cujo contingente aguardava manifestações da envergadura do ano anterior. Não houve confronto naquele dia e tampouco nos subsequentes, mesmo quando houve jogo em Porto Alegre. As ocorrências policiais durante a Copa em Porto Alegre foram rotineiras, e no restante do país não foi muito além disso. A final foi entre Argentina e Alemanha e a destacar, aqui, apenas os xingamentos obscenos dirigidos à presidente Dilma no Maracanã, um desfecho trágico para um megaevento tão celebrado e o prenúncio de que algo realmente grandioso estava por acontecer.

\section{Conclusões}

Péssima era a memória da última celebração nacional idealizada pelo Estado brasileiro, a malsucedida comemoração dos 500 anos da chegada dos colonizadores, um evento orquestrado pela lógica da publicidade, encompassada por uma narrativa ultrapassada sobre a identidade nacional e indiferente quanto ao impacto da colonização para os povos autóctones e para os imigrantes forçados. Em paralelo à celebração oficial, movimentos sociais ligados aos povos indígenas e quilombolas organizaram um protesto, para disseminar a sua visão a respeito do "descobrimento", sendo reprimidos pela polícia, no que poderia ser considerada uma performance bem mais coerente daquela montada pelas autoridades, por reeditar de forma compacta e espetacularizada a violência da qual esses grupos foram vítimas ao longo dos séculos. 
Há muito que o time da CBF é chamado de "seleção brasileira", "Brasil" ou "seleção", tendo-se tornado um dos mais potentes símbolos nacionais, e as Copas se constituíram como um tempo ritual de celebração laica da nação. Dada a participação destacada de negros na seleção desde a Copa de 1938, pode-se de fato considerá-la um símbolo dos mais representativos - excluindo-se as questões de gênero, evidentemente -, tendo-se tornado as copas um evento de interesse generalizado e interseccional. Em 2014 imaginava-se que a Copa poderia ser diferente, pois o Estado brasileiro era um ente consorciado da FIFA na organização do evento. Os discursos oficiais sugeriam uma apoteose: pelo fato de o Brasil ser anfitrião, potencializaria a celebração da nação, agregaria soft power e até promoveria vantagens econômicas. A escolha do país como país-sede não demandou uma disputa aberta, como no caso dos Jogos Olímpicos, e o Estado não precisou promover naquela ocasião uma narrativa acerca da nação, como faria em 2010, para defender a candidatura do Rio de Janeiro. No caso da Copa, preponderaram as tratativas de bastidores, e só por isso não houve na ocasião um equivalente ao filme produzido por Fernando Meirelles, apresentando o Brasil - e no caso o Rio de Janeiro - como um país multiétnico, harmonioso e hospitaleiro (DAMO; OLIVEN, 2013, p. 83-98). O discurso oficial do Estado brasileiro, com destaque para o do presidente Lula, seguia na mesma direção, apostando na unidade, na integração, na miscigenação e no protagonismo internacional.

Representações de brasilidade como essa fazem parte de uma narrativa desatualizada, sobretudo aos olhos de coletivos ligados a minorias - indígenas, negros, LGBT+, entre outros. Não seria surpresa, pois, se algum movimento social tentasse, estrategicamente, chamar a atenção da mídia internacional durante a Copa, mas as JsJ tornaram-se um emaranhado de reivindicações difusas. Não vivíamos no paraíso, mas alguns dos principais indicadores econômicos estavam no ápice - emprego formal, salário mínimo e distribuição de renda. Ensaiou-se uma hipótese de que a população teria se tornado mais exigente e ciosa de seus direitos, razão pela qual estaria desejando mais qualidade dos serviços públicos. Do ponto de vista político, muito se falou em crise de representação, mas também a esse respeito é difícil de conjugar a tese aos fatos se consideradas as alternativas escolhidas pela população posteriormente houve apoio popular ao Golpe Parlamentar e ao obscuro grupo de políticos sufragiados em 2018. Os protestos que principiaram com coletivos que pretendiam, supostamente, aprofundar as transformações - aqui agrupados sob o rótulo de insurgentes - acabaram cooptados, senão inteiramente, ao menos no essencial, por segmentos descontentes com a gestão petista, seja pelos avanços 
sociais promovidos, seja pelos tantos lapsos ou equívocos acumulados ao longo de mais de uma década de um dos períodos mais democráticos da história brasileira, em que se estenderam direitos no campo político, econômico e cultural.

Seguindo o argumento irônico de Fucks (2014), pode-se dizer que a ousadia e a imaginação pagaram um alto preço por se voltaram "contra tudo isso que está aí". "Tudo" virou "quase-nada" e "isso", um significante flutuante, virou sinônimo de "corrupção". Foram os intransigentes que lograram interpor o discurso da corrupção onde havia um vácuo, beneficiando-se, sobremaneira, de um evento futebolístico que mobiliza os sentimentos nacionalistas. Houve disputas durante as JsJ, mas a partir delas quem impôs as pautas foram grupos que se apropriaram, inclusive, de repertórios de ação coletiva aprendidos ao longo daquelas tardes e noites de junho de 2013 (BARBIERI, 2015). O fato é que as publicações mais recentes, no rescaldo das JsJ, estão avançando em perspectivas à época não vislumbradas, como é o fato, agora nítido, de que ocorreu, no decurso das próprias manifestações, uma torção ideológica e o mote da corrupção, uma narrativa facilmente assimilável pelo grande público, tornouse, efetivamente, o "isso" das JsJ.

Simone Guedes (2013), destacada antropóloga no campo dos estudos sobre futebol e identidade nacional, em manifestação oral durante a Reunião de Antropologia do Mercosul realizada em Córdoba, ainda em julho de 2013, foi taxativa quanto às influências futebolísticas sobre as JsJ. Havia a sobreposição das cronologias, o predomínio do verde e amarelo, a excitação juvenil, performances e pautas diversas que, em boa medida, lembravam muito a efervescência dos protestos futebolísticos, notórios pela intensidade e, simultaneamente, pela efemeridade. Um dos argumentos fortes de Simoni era de que não se poderia entender as JsJ deslocando-as do contexto dos rituais, e a prova cabal seria a cessão dos protestos assim que a Copa das Confederações fosse concluída, sem que as difusas reivindicações das ruas tivessem sido atendidas. De fato, não havia existido um evento determinando o desfecho das manifestações; a popularidade dos políticos havia sido arranhada - de todos, sem distinção ideológica - mas nenhum havia sido deposto; a repressão policial não havia atingido um pico, a que se pudesse atribuir a evacuação das ruas. Enfim, o país voltara à vida normal, como ocorre depois do Carnaval, de São João, do Réveillon ou das copas. Chamou a atenção, nas JsJ, o viés estético e performático; a excitação com que jovens e depois adultos se aventuraram nas ruas. Isso não elimina, em hipótese alguma, o viés político das manifestações, mas daquele cenário efervescente, polifônico e criativo, prosperou o seu oposto. 
As JsJ principiaram com protestos insurgentes e evoluíram rapidamente para um princípio de rebelião generalizada cujas consequências não foram maiores em razão da estabilidade econômica e política do período e, sobretudo, porque faltava um discurso coeso e uma liderança para orientá-la. O evento futebolístico contribuiu, sobremaneira, para fabricar a ideia de que os protestos não tinham uma orientação precisa - além da multiplicidade de pautas, havia se disseminado uma concepção horizontalista, identificada com um anarquismo pop. Se faltou, à época, um discurso de coesão à rebelião, pode-se, no entanto, aventar a hipótese que ela o suscitou. A narrativa de suspeição constituída no entorno da organização da Copa 2014, em particular das novas arenas, não apenas fez coincidir senão que acoplou, num tempo ritual, o discurso anti-establishment dos insurgentes com o antipetismo dos intransigentes. Os primeiros recuaram - ou foram forçados a tal, inclusive com o uso de violência - enquanto os últimos seguiram, agregando o legado aprendido nas ruas ao repertório on-line, com o qual tinham certa familiaridade. Fundiram a discurso anti-establishment com o antipetismo para produzir uma narrativa antipolítica emoldurada com a anticorrupção; uma trama sedutora, menos pela sofisticação e mais pela apelação e simplificação, em todo o caso capaz de promover a totalização da rebelião, e dela vicejaram, até o presente, traços abjetos de totalitarismo.

\section{Referências}

ALMEIDA, Marco Bettine; GUTIERREZ, Diego.

(2018). 0 soft power do Brasil e a cobertura da mídia internacional da Copa do Mundo da Fifa 2014. Licere, Belo Horizonte, v.21, n.2, p. 22557.

ANDREFF, Wladimir

(2010). Économie internationale du sport. Grenoble: PUG.

ARAÚJ0, Gabrielle Oliveira de Araujo.

(2014). Conflitos urbanos e a Copa 2014: a luta do Comitê da Copa de Porto Alegre pelo direito à moradia. Enfoques, v. 13, n. 1.

AVRITZER, Leonardo.

(2016). Impasses da democracia no Brasil. Rio de Janeiro: Civilização Brasileira.
BARBIERI, Alexia.

(2015). Do "FIFA go home" ao "fora Dilma": uma etnografia dos protestos de rua em Porto Alegre (2013-2015). TCC em Ciência Sociais/UFRGS.

BARBIERI, Alexia.

(2018). A nova onda liberal: uma análise antropológica do protagonismo e engajamento pró-liberalismo no Brasil contemporâneo. Dissertação de Mestrado, PPG Antropologia Social/UFRGS.

BENTES, Ivana.

(2014). Estéticas Insurgentes e Mídia-Multidão. Liinc em Revista, Rio de Janeiro, v.10, n.1, p.330-343.

BEZERRA, Arthur Coelho; GRILL0, Carolina Christoph.

(2014). Batalhas nas ruas, guerra nas redes: notas sobre a cobertura midiática da violência em 
manifestações. Liinc em Revista, Rio de Janeiro, v.10, n.1, p.195-210.

B0CCHI, Gabriel Moreira Monteiro

(2016). Do estádio Pacaembu para a Arena Corinthians: etnografia de um processo de "atualização". São Paulo: Dissertação de Mestrado em Antropologia Social/ Universidade de São Paulo.

BORGES, Helena.

(2017). “No fim das contas, o “0cupa Cabral” tinha razão. In: The Intercept_Brasil. Disponível em: https://theintercept.com/2017/09/22/no-fimdas-contas-o-ocupa-cabral-tinha-razao. Acesso em: 18 nov. 2019.

BOURDIEU, Pierre.

(1995). Razões Práticas. Campinas, Papirus.

CALLON, Michel.

(2013). Qu'est-ce qu'un agencement marchand?. In: CALLON, Michel et al. Sociologie des agencements marchands - Textes choisis. Paris: Presses des Mines, p. 325-440.

CAMPOS, Flávio.

(2014). Arquitetura da exclusão: apontamentos para a inquietação com o conforto. In: CAMPOS, Flávio; ALFONSI, Daniela (Orgs.). Futebol, objeto das ciências humanas. São Paulo:LeYa.

CAMPOS, Priscila Augusta Ferreira.

(2016). As formas de uso e a apropriação do estádio do Mineirão após a reforma. Campinas: Tese de Doutorado em Educação Física/UNICAMP.

CESARINO, Letícia.

(2014). Antropologia multissituada e a questão da escala: reflexões com base no estudo da cooperação sul-sul brasileira. Horizontes Antropológicos, v. 20, n. 41, p. 19-50.

CURI, Martin.

(2012). Espaços da emoção: arquitetura futebolística, torcida e segurança pública. Tese de Doutorado em Antropologia, Universidade Federal Fluminense, Niterói.

DA SILVA, Camila F.

(2016). Inovações nos Repertórios de Contestação:

0 Confronto em Torno do Transporte Público em
Porto Alegre. Dissertação de Mestrado em Sociologia UFRGS.

DAM0, Arlei; OLIVEN, Ruben.

(2013). 0 Brasil no horizonte dos megaeventos esportivos de 2014 e 2016: sua cara, seus sócios e seus negócios. Horizontes Antropológicos, v. 19, n. 40, p. 19-63.

(2014). Megaeventos esportivos no Brasil. Autores Associados:Campinas.

DAM0, Arlei

(2016). Dinheiro público em megaeventos esportivos: a eficácia de uma justificativa inconsistente. Ciência e Cultura, vol. 68, n.2, p. 27-31.

DRULA, Andréia Juliane.

(2015). O processo de transformação de um estádio para arena: o caso da Arena da Baixada. Curitiba: Dissertação de Mestrado em Educação Física/UFPR.

DUKE, Vic.

(1994). The drive to modernization and the supermarket imperative: who needs a new football stadium?. In: GIULIANOTI, R; WILLIAMS, J.(orgs.) 1994. Game without forntiers: football, identity and modernity. Adershot: Arena, Brookfield: Ashgate, p. 129152.

D'ANDRÉA, Carlos Frederico de Brito.

(2014). Editando a violência: os vídeos "amadores" de quatro webTVs jornalísticas sobre as Jornadas de Junho. Liinc em Revista, Rio de Janeiro, v.10, n.1, p.285-300.

DAS, Veena.

(1995). Critical Events: An Anthropological Perspective on Contemporary India. New Delhi: 0xford University Press.

DAVIES, Frank Andrew.

(2017). Deodoro: formas de governo para uma "região olímpica". Rio de Janeiro, tese de doutorado, Instituto de Ciências Sociais da Universidade do Estado do Rio de Janeiro. 
FREIRE, Leticia de Luna.

(2013). Mobilizações coletivas em contexto de megaeventos esportivos no Rio de Janeiro. 0 Social em Questão, ano XVI, n. 29.

FRUGOLI JR., Heitor.

(2018). Ativismos Urbanos em São Paulo. Cad. CRH, Salvador , v. 31, n. 82, p. 75-86, abr

FUKS, Julián.

(2014). As vozes das ruas dizem tudo e nada. Ide (São Paulo), São Paulo, v. 36, n. 57, p. 17-23, jun.

GIGLIO, Sérgio Settani.

(2018). A história política do futebol olímpico (1894-1988). São Paulo: Intermeios/FAPESP.

GOHN, Maria da Glória.

(2017). Manifestações e protestos no Brasil: correntes e contracorrentes na atualidade. São Paulo: Cortez.

GONÇALVES, Murilo Gelain.

(2019). Bandeiras, pedras e tambores: atuação dos anarquistas nas Jornadas de Junho a partir do Bloco de Lutas Pelo Transporte Público. Dissertação de Mestrado em Antropologia Social/UFRGS.

GONDIM, Linda M. P.

(2016). Social movements in contemporary Brazil: the invisible face of the June 2013 protests. Polis, Santiago, v. 15, n. 44, p. 357-379.

GUEDES, Simoni.

(2013). El Brasil reinventado. Notas sobre las manifestaciones durante la Copa de las Confederaciones. Nueva Sociedad, n. 248, p. 89100.

GUTTERRES, Anelise dos Santos.

(2014). A resiliência enquanto experiência de dignidade: antropologia das práticas políticas em um cotidiano de lutas e contestações junto a moradoras ameaçadas de remoção nas cidades sede da Copa do Mundo 2014. Tese de Doutorado em Antropologia Social/UFRGS.

HAUBRICH, Alexandre.

(2018). Nada Será Como Antes - 2013, o ano que não acabou, na cidade onde tudo começou. Porto Alegre: Libretos.
HERMANN, Herbert; DAM0, Arlei.

(2014). Mobilização Kaingang para a Copa 2014 ? notas etnográficas a partir de Porto Alegre. Ponto. Urbe (USP), v. 15, p. 1-21.

HOLLANDA, B.; MEDEIROS, J.

(2019). De "país do futebol" a "país dos megaeventos": um balanço da modernização dos estádios brasileiros sob a ótica das torcidas organizadas da cidade de São Paulo. Recorde: Revista de História do Esporte, vol. 12, n.1.

HOLLANDA, Bernardo Borges Buarque de.

(2014). 0 fim do estádio-nação? Notas sobre a construção e remodelagem do Maracanã para a Copa de 2014. In: CAMPOS, Flávio; ALFONSI, Daniela. (Org.). Futebol objeto. São Paulo: Leya, p. 321-348.

INGOLD, Tim

(2012). Trazendo as coisas de volta à vida: emaranhados criativos num mundo de materiais. Horizontes Antropológicos, Porto Alegre, v. 18, n. 37, p. 25-44.

JENNINGS, Andrew.

(2011). Jogo Sujo: o mundo secreto da FIFA. São Paulo: Panda Books.

JURIS, Jeffrey S.

(2005). Violence Performed and Imagined Militant Action, the Black Bloc and the Mass Media in Genoa. Critique of Anthropology, vol. 25, n. 4, p. 413-432.

MAGALHAES, Alexandre

(2013). 0 "legado" dos megaeventos esportivos: a reatualização da remoção de favelas no Rio de Janeiro. Horizontes Antropológicos, v. 19, n. 40, p. 89-118.

MAGALHAES, Alexandre.

(2019). A "lógica da intervenção" e a questão da circulação: As remoções de favelas como forma de gerir o espaço urbano no Rio de Janeiro dos Jogos Olímpicos. Tempo Social, v. 31, n. 2, p. 221-242.

\section{MARENC0, André}

(2014). As duas caudas de Gauss: minorias, protesto e representação política. In: CATTANI, Antônio David (org.) \#protestos - análise das 
ciências sociais. Porto Alegre: Tomo Editorial, p. 31-41.

MARICATO, E.

(2013). “É a questão urbana, estúpido!". In: MARICATO, E. et al. Cidades rebeldes: passe livre e as manifestações que tomaram as ruas do Brasil, São Paulo, Boitempo/Carta Maior

MARSTON, Sallie A.

(2000). The social construction of scale. Progress in Human Geography, v. 24, n. 2, p. 219-242.

MASCARENHAS, Gilmar.

(2009). “Globalização e espetáculo: o Brasil dos megaeventos

esportivos". In: Del PRIORE, Mary; MELO, Victor Andrade de. (Orgs.). História do esporte no Brasil: do império aos dias atuais. São Paulo: Unesp, p. 505-533.

MEL0, Cristina Teixeira Vieira de; VAZ, Paulo Roberto Givaldi.

(2018). E a corrupção coube em 20 centavos. Galaxia (São Paulo, online), n. 39, p. 23-38.

MENDONÇA, Ricardo Fabrino.

(2017). Singularidade e identidade nas manifestações de 2013. Revista do Instituto de Estudos Brasileiros, Brasil, n. 66, p. 130-159.

MENDONÇA, Ricardo Fabrino.

(2018). “Dimensões democráticas nas Jornadas de Junho reflexões sobre a compreensão de democracia entre manifestantes de 2013. Revista Brasileira de Ciências Sociais, vol. 33, n. 98, p. 123.

MESOMO, Juliana.

(2014). Cotidiano em Suspenso: remoção de populações e mobilização coletiva no contexto de duplicação da Avenida Tronco em Porto Alegre-RS. Dissertação de Mestrado em Antropologia Social/UFRGS.

MESOM0, Juliana; DAM0, Arlei.

(2016). Remoção de populações em meio urbano: princípios, tecnologias e a mediação dos impactos a partir de Porto Alegre. In: URIARTE, Urpi Montoya; MACIEL, Maria Eunice. (Org.). Patrimônio, Cidades e Memória Social. Salvador: EDUFBA, p. 73-94.
MORAES, Isaias Albertin; VIEIRA, Fernando Antônio da Costa.

(2017). As Jornadas de Junho de 2013 no Brasil: anarquismo e tática Black Blocs. Século XXI, Revista de Ciências Sociais, v.7, no 2, p.165-198.

MUHALE, Miguel J.J.

(2014). Lutar, construir poder popular: Uma perspectiva etnográfica do Bloco de Lutas pelo Transporte Público em Porto Alegre/RS. Dissertação de Mestrado em Antropologia Social/UFRGS.

NASCIMENTO, Cristiano Felipe Borba

(2013). O edifício Gadget. Da relação entre função, espaço e forma em tipos arquitetônicos contemporâneos globais - o caso dos estádios de futebol. Tese de Doutorado em Desenvolvimento Urbano/UFPE.

OLIVEIRA Jr, Ricardo César Gadelha de.

(2017). "A reviravolta dos "fanáticos": arenização, agenciamentos mercadológicos e novos movimentos políticos a partir do Sport Club Internacional. Tese de Doutorado. PPG Antropologia Social/UFRGS, Porto Alegre, 2017.

OLIVEIRA, Rodrigo Perez Oliveira.

(2018). 0 significado do conceito "corrupção" na semântica política da crise brasileira (20132016). Anos 90, Porto Alegre, v. 25, n. 48, p. 379-408.

ONG, A.; COLLIER, S. (0rg.).

(2005). Global assemblages: technology, politics and ethics as anthropological problems. Malden: Blackwell.

ORTELLAD0, Pablo.

(2013). Em 20 centavos: a luta contra o aumento. São Paulo: Veneta.

PARIS, Jeffrey.

(2003). The Black Bloc's Ungovernable Protest. Peace Review, v. 15, n. 3, p. 317-322.

REBELO, Aldo; TORRES, Silvio.

(2001). CBF-NIKE. São Paulo:Casa Amarela.

ROCHA, Camila.

(2015). Direitas em rede: think tanks de direita na América Latina. In: CRUZ, S.; KAYSEL, A. e KODAS, G. (Org.). Direita, volver: o retorno da direita e o 
ciclo político brasileiro. São Paulo: Editora Fundação.

ROLNIK, Raquel.

(2011). Megaeventos e violações de direitos humanos no Rio de Janeiro: Dossiê do comitê popular da Copa e Olimpíadas do Rio de Janeiro. Disponível em:

http://comitepopulario.files.wordpress.com/20 12/04/dossic3aamegaeventos-e-

violac3a7c3b5es-dos-direitos-humanos-no-riode-janeiro.pdf. Acesso em: 15 nov. 2019.

SAHLINS, Marshall.

(1990). Ilhas de História. Rio de Janeiro, Jorge Zahar.

SANTOS, Irlan S.

(2017). Clientes versus Rebeldes - Novas culturas torcedoras nas arenas do futebol moderno. Rio de Janeiro: Multifoco.

SARAIVA, Adriana C.

(2014). Movimento Passe Livre e Black Blocs: quem são os novos atores que emergiram dos protestos de 2013. CATTANI, Antonio D. (org.). \#protestos: análises das ciências sociais. Porto Alegre: Tomo Editorial.

SCALON, Celi.

(2013). Juventude, igualdade e protestos. Revista Brasileira de Sociologia, v. 1, n. 2, p. 178-204.

SCHECHNER, Richard.

(2011). "Pontos de contato entre o pensamento antropológico e teatral". In: Cadernos de Campo, São Paulo, n. 20, p. 213-36.

SCHERER-WARREN, Ilse.

(2014). Manifestações de rua no Brasil 2013: encontros e desencontros na política. Cadernos CRH, v. 27, n. 71, p. 417-429.

SCOT, Parry; MOURA, Alice Bezerra de Mello. (2014). Desapropriações, Resistências e o Megaevento da Copa do Mundo: tempo, poder e projetos de desenvolvimento. Revista Anthropológicas, v. 25, n. 2, p. 94-132.
SEGARRA, Josep J.

(2015). "Paz entre nós, guerra aos senhores!": Uma etnografia sobre o Bloco de Lutas pelo Transporte Público e a 0cupação da Câmara de Vereadores de Porto Alegre. 2015. Dissertação de Mestrado em Antropologia Social/UFRGS.

SILVA, Regina Helena Alves da; ZIVIANI, Paula.

(2018). "Temporalidades emaranhadas": desafios metodológicos da dinâmica dos protestos em rede de 2013 no Brasil. Revista Crítica de Ciências Sociais, n. 117, p. 27-46.

SINGER, André.

(2013). Brasil, junho de 2013: classes e ideologias cruzadas. Novos Estudos, São Paulo, n. 97, p. 2240.

SOLANO, Esther; MANSO, Bruno P. Mascarados.

(2014). A verdadeira história dos adeptos da tática Black Bloc. São Paulo: Geração Editorial.

TAMBIAH, Stanley.

(1997). Conflito Etnonacionalista e Violência Coletiva no Sul da Ásia. In: Revista Brasileira de Ciências Sociais, v. 12, n. 34, p. 5-37.

TAVARES, Francisco Mata Machado; RORIZ, João Henrique Ribeiro; OLIVEIRA, Ian Caetano de.

(2013). As jornadas de maio em Goiânia: para além de uma visão sudestecêntrica do junho brasileiro em 2013. Opin. Publica, vol.22, n.1, p.140-166.

TSING, Anna.

(2000). "The global situation", Cultural Anthropology, v. 15, n. 3, p 327-360.

\section{Recebido em}

janeiro de 2020

\section{Aprovado em}

junho de 2020 